\title{
Inter-observer variation in the triage-process
}

\author{
Hanne Jørsboe ${ }^{1 *}$, Maya Schrøder $^{1}$, Marianne Koch Barylak, Philip Anderson ${ }^{2}$ \\ From Danish Society for Emergency Medicine: Research Symposium 2010 \\ Roskilde, Denmark. 20-21 May 2010
}

\section{Background}

Triage algorithms for sorting patients according to their severity of illness have recently been implemented at several emergency departments in Denmark. Clinical effectiveness and safety depend on standardization of the triage process. We implemented a 5-level triage algorithm for which triage nurses underwent an initial training. The aim of this study was to evaluate the degree of standardization in implementation of triage by measuring the level of agreement among retrospective reviewers of the triage scores.

\section{Methods}

Six months after implementation, we studied the interobserver variation among our 5 triage nurses. Cases triaged by each nurse underwent two separate retrospective evaluations by all 5 triage nurses based on documentation of a) pre-arrival information, and b) pre-arrival information plus triage vital signs and clinical information gathered on arrival. Kappa-statistic was used to evaluate pair-wise agreement among the retrospective reviewers for each of the two retrospective evaluations, and also between the original triage score and second retrospective review.

\section{Results}

A total of 100 cases (20 consecutive cases triaged by each nurse) were evaluated. The distribution of initial triage scores was 1 red (highest acuity), 27 orange, 48 yellow, 24 green, zero blue (lowest acuity). Weighted kappa-score for pair-wise agreement among triage nurses for the two retrospective reviews were 0.40 (range: 0.24-0.56), and 0.41 (range: 0.38-0.46). Weighted kappa-score for pair-wise agreement between original triage score and each retrospective reviewer (pre-arrival

\footnotetext{
* Correspondence: hbjo@regionsjaelland.dk

${ }^{1}$ Akutafdelingen, Nykøbing Sygehus, Denmark

Full list of author information is available at the end of the article
}

information + triage vital signs and clinical information) was 0.45 (range: $0.34-0.58$ ).

\section{Conclusion}

These results show, for the first time in Denmark, that moderate agreement can be achieved within a short period of time following implementation of an emergency department triage program with a brief initial training. A limitation of this study is that we did not systematically evaluate the completeness of the clinical documentation upon which the retrospective triage evaluations were made. Variability in the completeness of the clinical documentation may contribute to variability in the scoring. Quality assurance feedback and continuing triage nurse education are indicated to improve the standardization of triage scoring.

\section{Author details \\ 'Akutafdelingen, Nykøbing Sygehus, Denmark. ${ }^{2}$ Dept. of Emergency \\ Medicine, Beth Israel Deaconess Medical Center, Boston, MA, USA.}

Published: 17 September 2010

doi:10.1186/1757-7241-18-S1-P16

Cite this article as: Jørsboe et al:: Inter-observer variation in the triageprocess. Scandinavian Journal of Trauma, Resuscitation and Emergency Medicine 2010 18(Suppl 1):P16.

Submit your next manuscript to BioMed Central and take full advantage of:

- Convenient online submission

- Thorough peer review

- No space constraints or color figure charges

- Immediate publication on acceptance

- Inclusion in PubMled, CAS, Scopus and Google Scholar

- Research which is freely available for redistribution

Submit your manuscript at www.biomedcentral.com/submit
C Biomed Central 